DOI: $10.15290 /$ bsl.2021.18.09

\author{
Anna Piniewska \\ Wydział Polonistyki \\ Uniwersytet Warszawski \\ e-mail: a.piniewska@student.uw.edu.pl \\ ORCID: 0000-0002-8474-8037
}

\title{
Splot głosów. Mowa pozornie zależna w Requiem dla gospodyni Wiesława Myśliwskiego
}

Dramaturgia Wiesława Myśliwskiego nie doczekała się monograficznego ujęcia; badacze i badaczki często ją marginalizują jako nieskomplikowaną formalnie ${ }^{1}$. Sądzę jednak, że dramaty autora Pałacu powinny zostać wydobyte $\mathrm{z}$ cienia wielkich powieści; są one bowiem interesujące $\mathrm{w}$ perspektywie poetologicznej. Niebagatelną rolę $\mathrm{w}$ ich ukształtowaniu formalnotekstowym, zwłaszcza w przypadku Złodzieja ${ }^{2}$ i Requiem dla gospodyni³, odgrywa mowa pozornie zależna ${ }^{4}$. Obecność tej formy podawczej w dramacie nie została na-

1 „Dzieła dramaturgiczne nie przyniosły Wiesławowi Myśliwskiemu takiego uznania jak powieści. Przez krytyków bywały nieraz traktowane jak słabiej rozwinięte, mniej samodzielne skrzydło jego twórczości" [E. Wąchocka, Kwartet dramatyczny Wiesława Myśliwskiego, w: Myśl Myśliwskiego (studia i eseje), red. J. Olejniczak, Katowice 2018, s. 282]; „Myśliwski dramaturgiem nie jest - jego trzy utwory sceniczne są raczej dialogami o bardzo klasycznej formie, lekce sobie ważącej dążenia nowoczesnej dramaturgii" [B. Kaniewska, Wiesław Myślizwski, Poznań 1995, s. 16].

2 W. Myśliwski, Złodziej, „Dialog” 1973, nr 7.

3 W. Myśliwski, Requiem dla gospodyni, w: Trans/formacja. Dramat polski po 1989 roku. Antologia, red. J. Kopciński, Warszawa 2012, t. 1. W artykule cytaty pochodzą z wydania w publicznym dostępie: W. Myśliwski, Requiem dla gospodyni. Sztuka w dwóch aktach, https://shron1.chtyvo.org. ua/Myslyvskyi_Vieslav/Requiem_dla_gospodyni_pol.pdf?PHPSESSID=mjj0svdukn9ddn01nm 18rj7lb3, [dostęp 09.06.2021]. W dalszej części tekstu wskazuję lokalizację cytatu, posługując się skrótem „R" i podając numer strony.

4 W twórczości prozatorskiej Myśliwskiego mowa pozornie zależna jest istotną i często wykorzystywaną techniką narracyjną, w związku z czym porównanie użycia tej formy w prozie 
ukowo opisana. Badania na temat jej wpływu na strukturę dramatu wymagałyby osobnego opracowania. Celem niniejszego artykułu będzie zatem studium przypadku - analiza Requiem dla gospodyni z uwzględnieniem zagadnienia mowy pozornie zależnej (w semantycznym, nie syntaktycznym ujęciu ${ }^{5}$ ).

Jako że na gruncie dramatologii dyskusja na temat mowy pozornie zależnej się nie odbyła - świadoma różnic genologicznych i formalnych - odwołam się do teorii prozy. Nie ma tutaj miejsca na szczegółową rekonstrukcję stanu badań ${ }^{6}$, należy jednak przyjąć określone stanowisko $\mathrm{w}$ sporze dotyczącym tego "kto mówi?" istotne także dla dramatu. Teoretycy mowy pozornie zależnej odpowiadają na nie zgodnie z jedno- lub dwugłosową koncepcją. Najbardziej znanymi przedstawicielami tej pierwszej są m. in. Charles Bally, twierdzący, że mówi postać, a narrator spełnia jedynie funkcje "tuby" ${ }^{8}$ oraz Wojciech Tomasik, który wskazuje na narratora, a mowę pozornie zależną rozpatruje jako wypowiedź z ograniczoną odpowiedzialnością podmiotu ${ }^{9}$. Patronem koncepcji dwugłosowych, w ramach których sytuuję swoje myślenie, jest Wołoszynow-Bachtin, twierdzący, że: „mówi i bohater, i autor równocześnie, że [...] w gra-

i dramacie mogłoby stanowić przedmiot osobnego studium. Zagadnienie to można by wówczas analizować poprzez zestawienie dramatów „ludowych” z powieściami wpisującymi się w nurt chłopski oraz porównanie sztuk z utworami wydanymi po Kamieniu na kamieniu - zdaniem niektórych badaczy - zamykającego nurt chłopski w literaturze polskiej [zob. np. D. Kulesza, Poza granicami literatury. Historia świata wedtug Edwarda Redlińskiego, w: Spotkania w przestrzeni idei - słów - obrazów. Księga Pamiątkowa dedykowana prof. dr hab. Zofii Mocarskiej-Tycowej, red. J. Bielska-Krawczyk, K. Ćwikliński i S. Kołos, Torun 2012].

5 „Mowa pozornie zależna wzbudziła wiele polemik, a w ich toku wyłoniły się dwa nurty przeciwstawiające syntaktyczne i semantyczne jej ujęcie" [J. Jakubowska-Cichoń, Mowa przytaczana w narracjach Marguerite Duras, Kraków 2010, s. 18].

6 W celu zapoznania się z refleksją nad mową pozornie zależną, zob. np. W. Tomasik, Od Bally'ego do Banfield [i dalej]. Sześć rozpraw o "mowie pozornie zależnej", Bydgoszcz 1992; D. Hopensztand, Mowa pozornie zależna w kontekście "Czarnych skrzydet”, w: Prace ofiarowane Kazimierzowi Wóycickiemu, Wilno 1937, https://polona.pl/item/mowa-pozornie-zalezna-wkontekscie-czarnych-skrzydel,Njc4NjE3NzY/4/\#info:metadata, [dostęp 09.06.2021]; K. Wóycicki, Z pogranicza gramatyki i stylistyki. (Mowa zależna, niezależna i pozornie zależna), „Przegląd Humanistyczny" 1922, t. 1, https://polona.pl/item/z-pogranicza-gramatyki-i-stylistyki-mowazalezna-niezalezna-i-pozornie-zalezna,Njc4NzI4MDY/4/\#info:metadata, [dostęp 09.06.2021]; J. Jeziorska-Haładyj, Mowa pozornie zależna; Mowa i myśl (pozornie zależna), w: J. Jeziorska-Haładyj, Tekstowe wykładniki fikcji. Na przykładzie reportażu i powieści autobiograficznej, Warszawa 2013; M. Głowiński, Powieść młodopolska. Studium z poetyki historycznej, Wrocław - Warszawa - Kraków 1969. B. Cerquiglini, Mowa pozornie zależna i nowoczesność, przeł. M. Abramowicz, „Pamiętnik Literacki” 1990, nr 4.

7 Odnoszę się do tytułu artykułu Tomasika. Por. W. Tomasik, Kto mówi?: jeszcze o mowie pozornie zależnej, „Pamiętnik Literacki” 1992, nr 4.

8 Tamże, s. 113.

9 Tamże, s. 114. 
nicach jednej konstrukcji językowej zostają zachowane akcenty dwóch głosów różnie ukierunkowanych" ${ }^{10}$. Obecność tej formy w dramacie prowokuje zatem do postawienia pytań na temat relacji wewnątrztekstowych instancji nadawczych i mowy dramatycznej. Zagadnienia te wymagałyby opracowania $\mathrm{w}$ osobnym studium, chciałabym jednak podkreślić, że na wiele istotnych problemów naprowadza już analiza dramaturgii Myśliwskiego.

Dla Wołoszynowa ważny jest również socjologiczny aspekt przytoczeń: dynamika mowy cudzej i autorskiej oddaje "dynamikę wzajemnego ustosunkowania się społecznego ludzi pozostających w kontakcie językowo-ideologicznym" ${ }^{\prime 1}$. Badanie tejże dynamiki oraz hierarchizacji głosów może stanowić użyteczne narzędzie opisu wypowiedzi postaci dramatu. Uwzględnienie rozważań Wołoszynowa wskazuje nie tylko na formalne kwestie, lecz także semantyczne. W Requiem mowy pozornie zależnej używa przede wszystkim Boleś, za każdym razem reprodukujący słowa zmarłej Gospodyni, w związku z czym analiza relacji zachodzących pomiędzy głosami bohaterów ${ }^{12}$ jest kluczowa dla interpretacji utworu.

Fabuła dramatu „ludowego"13 Myśliwskiego jest zorganizowana wokół wiejskiego rytuału czuwania. Jak zauważa Marian Lewko, to: „okrutna i bolesna diagnoza pogrzebu chłopskiej kultury, zarazem pełen goryczy dramat o naszym stosunku do śmierci"14. Młodsze postaci, reprezentujące nowy porządek kulturalny, postrzegają ów rytuał jako niecodzienne

10 W.N. Wołoszynow, Z historii form wypowiedzi w konstrukcjach języka. (Próba zastosowania metody socjologicznej do zagadnień składni), przeł. Z. Saloni, w: Rosyjska szkoła stylistyki, oprac. M.R. Mayenowa, Z. Saloni, Warszawa 1970, s. 456. Wydaje mi się, że nie ma potrzeby, by odwoływać się do klasycznych ustaleń Bachtina dotyczących dwugłosowego słowa i stosunków dialogowych, niemniej warto o nich pamiętać. Por. M. Bachtin, Stowo w dziele Dostojewskiego, w: tegoż, Problemy poetyki Dostojewskiego, przeł. N. Modzelewska, Warszawa 1970.

11 W.N. Wołoszynow, Z historii form wypowiedzi w konstrukcjach języka, s. 422.

12 Ze względu na ograniczoną formę artykułu uwagę poświęcam zagadnieniu postaci, zauważyć jednak należy, że w przypadku dwugłosowej mowy pozorne zależnej w dramacie problem relacji podmiot dramatyczny - postać również wymagałaby opracowania.

13 Używam tego terminu za Olszewską [M.J. Olszewska, "Tragedia chłopska”. Od W.L. Anczyca do K.H. Rostworowskiego. Tematyka - Kompozycja - Idee, Warszawa 2001, s. 13]. Twórczość sceniczną Myśliwskiego - w perspektywie dramaturgii ludowej - badała J. Betkowska w pracy Polski dramat ludowy (1945-1989), rozprawa doktorska obroniona na wydziale Filologiczno-Historycznym Akademii Pomorskiej w Słupsku, 2019.

14 M. Lewko, Świat wewnętrzny bohaterów chłopskich w dramaturgii Wiesława Myśliwskiego, w: O twórczości Wiestawa Myśliwskiego (w siedemdziesiąta rocznicę urodzin pisarza), red. J. Pacławski, Kielce 2001, s. 100. 
przeżycie, a chłopską wiarę sprowadzają do folkloru: „Turystka I: Ależ to tylko obyczaj. Folklor. Dlaczego państwo tak... na poważnie" [R, s. 77]. Dla Myśliwskiego folklor - co wybrzmiało w eseju Kres kultury chłopskiej ${ }^{15}$ - to pojęcie nacechowane pejoratywnie, nie mające nic wspólnego z chłopskim losem.

Śmierć na wsi była dawniej postrzegana jako doświadczenie zbiorowe wielkiej wagi, w którym wspólnie przeżywano ból ${ }^{16}$ towarzyszący stracie członka społeczności. Jedynie Gospodarz i Boleś o tym pamiętają. Pastuch jednak nie chce pogodzić się ze śmiercią Gospodyni, co staje się pretekstem do połączenia dwóch planów w dramacie: realistycznego oraz wizyjnego ${ }^{17}$. Także wypowiedzi Bolesia w mowie pozornie zależnej można podzielić według tego klucza. Boleś przywołuje słowa Gospodyni sprzed jej śmierci, które faktycznie zostały wyartykułowane; to wspomnienia mieszczące się w konwencji realistycznej. Pastuch przytacza też wypowiedzi Gospodyni-zjawy $\mathrm{w}$ trzech wcieleniach (młodej dziewczyny, kobiety w ciąży oraz w podeszłym wieku), z którą - co należy podkreślić - on jeden ma kontakt. Te sytuacje komunikacyjne odnoszą się do pierwiastka fantastycznego. W dalszej części rozważań podejmę się charakterystyki przykładów wybranych z obu planów.

W dialogu Gospodarza i Bolesia o makatce, ten drugi przypomina słowa Gospodyni i jej instrukcje, jak zawiesić tę dekorację na ścianie; to wspomnienie faktycznej rozmowy z przeszłości.

Boleś: (szukajac miejsca na ścianach dla makatki) Wasze palce niezdatne, powiedziała. Guzika do koszuli nie umieliście nawet przyszyć. Weź ty, Boleś, wyszyj. (I przymierzając makatkę na ścianie) Dobrze tu będzie?

Gospodarz: Nad kuchnią byłoby lepiej. Chciała, żeby nad kuchnią.

Boleś: Nad kuchnią zaparuje, owędzi się i zaraz pierz. A kto będzie teraz prał? Weronka? Sama się opierze i ma resztę gdzieś. Pralkę trzeba kupić. Obiecywaliście gospodyni. I co? Całe życie przy balii i tarce jej zeszło. Ręce miała nieraz aż sine. Bo wam zawsze szkoda było. Ale na dokupywanie ziemi nie było [...] [R, s. 15].

\footnotetext{
15 W. Myśliwski, Kres kultury chłopskiej, Warszawa-Bochnia: Prowincjonalna Oficyna Wydawnicza, http://mbc.malopolska.pl/dlibra/docmetadata?id=3631\&from=publication [dostęp 09.06.2021].

16 E. Wąchocka, Śmierć w nowych dekoracjach, w: Intymne - prywatne - publiczne, red. E. Wąchocka, Katowice 2015, s. 286.

17 Zdaje się, że m. in. dlatego Requiem zestawia się z Weselem Stanisława Wyspiańskiego. Por. D. Kulesza, Epopeja. Myśliwski, Herbert, Mrożek, Białystok 2016, s. 121.
} 
Z kontekstu wynika, że Boleś rozmawiał kiedyś o makatce z Gospodynią. Użyte wówczas przez nią słowa przywołuje w pierwszej wypowiedzi. Przytoczenie jest wyraźnie zasygnalizowane („powiedziała”), w związku z czym granica pomiędzy głosami mężczyzny i kobiety jest widoczna. Owe głosy jednak trudno jednoznacznie sklasyfikować, gdy Boleś odzywa się po raz drugi. Zdanie o kuchni można by przypisać zarówno Bolesiowi (wówczas byłby to komentarz do propozycji Gospodarza), jak i Gospodyni (jako świadectwo wcześniejszej rozmowy). Uprawnione wydaje się potraktowanie podobnie ostatnich dwóch zdań. Jako że nie ma tutaj żadnych tekstowych wskazówek, czytelnik nie wie, czy jest to przytoczenie słów Gospodyni (bez informacji na zewnątrz przytoczenia ${ }^{18}$ ), czy po prostu zdanie Bolesia. Ta niejednoznaczność, jak sądzę, jest celowym zabiegiem, który wywołuje wrażenie splotu głosów Gospodyni i Bolesia. Podobne odczucie można mieć podczas lektury krótkiego fragmentu z ostatniego monologu Pastucha: „Lubiła jaskółki [Gospodyni - dop. A.P.] Bo taką jaskółkę co ten świat obchodzi? Co ją ludzie obchodzą? Wciąż pod niebem" [R, s. 109]. Skoro mężczyzna wspomina, że kobieta lubiła ptaki (tym samym przekierowuje uwagę czytelnika na jej postać), uprawnione wydaje się przypisanie refleksji na temat jaskółek Gospodyni. Być może jest to wspomnienie rozmowy, którą bohaterowie odbyli kiedyś w przeszłości. Teza, że to głos Bolesia, również jest zasadna, ponieważ motyw jaskółki wielokrotnie uobecniał się w jego opowieściach. $Z$ treści dramatu wynika, że relacja łącząca dwoje bohaterów była niezwykle silna, wydaje się zatem, że to "połączenie” głosów, niemożność postawienia granicy pomiędzy przytaczającym a przytaczanym, wiąże się właśnie z tą zażyłą relacją. Tak, jakby miała ona odzwierciedlenie również w języku; jakby mówili tymi samymi słowami. W tym kontekście warto pamiętać refleksję Wołoszynowa o dynamice głosów i socjologicznych aspektach przytoczenia.

Interpretacja przykładów wpisujących się w nierealistyczny plan dramatu, gdy Boleś przytacza słowa zjawy, związana jest z przyjęciem konkretnej perspektywy. Czytelnik de facto wie, że żadna z opisywanych przez

\footnotetext{
18 O wewnętrznych i zewnętrznych wskaźnikach przytoczenia, za Bally'm, pisał Wóycicki. Zewnętrzne dotyczą bezpośredniego użycia leksemów sygnalizujących przytoczenie; wewnętrzne powstają w obrębie samej wypowiedzi w mowie pozornie zależnej (pochodzą nie tylko od autora, lecz także od postaci). Zob. K. Wóycicki, Z pogranicza gramatyki i stylistyki. (Mowa zależna, niezależna i pozornie zależna), s. 85.
} 
Bolesia rozmów nie miała miejsca, a więc wszystkie przywołane słowa Gospodyni są zmyśleniem (nigdy nie zostały wypowiedziane). Wówczas pytanie o podmiot (podmioty?) wypowiedzi jest bezzasadne. Mówi Boleś, który - jako wiejski szaleniec - z tęsknoty za Gospodynią wyobraża sobie spotkania z nią. Takie podejście wydaje się jednak ograniczające. Dlatego też decyduję się uwzględnić punkt widzenia Bolesia wierzącego, że rozmawia z Gospodynią. Następnie wykażę, że jest to również punkt widzenia uprzywilejowany przez podmiot dramatyczny.

Boleś trzykrotnie widzi się z kobietą-zjawą i to jedyne momenty, gdy odbiorca tekstu jest bezpośrednim świadkiem ich dialogu:

Boleś: A tę melodię gospodyni pamięta? Lubiła ją [...].

Gospodyni: (z bolesna zawziętością) Nie lubiłam! Nie lubiłam! Żadnej nie lubiłam. Boleś: Graj, Boleś, graj. Tak pięknie grasz, aż chce mi się tańczyć. Taka czuję się młoda, Boleś. I tańczyła jak łąka szeroka [R, s. 51].

Powyższy przykład jest interesujący, ponieważ Boleś przytacza w mowie pozornie zależnej słowa Gospodyni i je do niej kieruje. Można się zastanawiać, czy to wspomnienie z przeszłości (faktyczna wypowiedź Gospodyni, gdy jeszcze żyła), czy również zmyślenie Bolesia. Nie sądzę, by dało się rozstrzygnąć tę kwestię; przywołuję ten fragment, ponieważ komplikuje omawiane zagadnienie. Co ciekawe, identyczna konstrukcja składniowa występuje w Drzewie: „Duda: Mojej [żonie - dop. A.P.] tak ten walczyk się podobał, że całe wesele kazała ci go grać. Graj, Stachu, i graj Stachu. I nic tylko tego walczyka"19. Użycie mowy pozornie zależnej zaświadcza o bliskiej relacji Dudy i jego zmarłej żony. Ich zażyłość - tak jak w przypadku Bolesia i nieżyjącej Gospodyni - oddana jest w splocie dwóch głosów.

W Requiem pojawiają się także nieoczywiste wypowiedzi, które nie są klasyczną mową pozornie zależną, jednak poetyki mowy niezależnej również $\mathrm{w}$ pełni nie realizują:

Boleś: Była u mnie na łąkach [Gospodyni - dop. A.P.].

Gospodarz: Gdzie była? Gdzie była? O, tam leży.

Boleś: Mówię, była to była. Pogłaskała mnie po policzku. Dotąd czuję. Przyniosła mi chleba z serem, dwa jaja, mleka w butelce. Poleciała krowy za mnie nawrócić. A ty siedź, jedz, odpocznij trochę, Boleś. Co tu odpoczywać, gospodyni.

19 W. Myśliwski, Drzewo, s. 77. 
Za krowami cały czas się odpoczywa. Od odpoczywania kości mi się zastały. To poganiajmy się po łące, rozruszają ci się, chcesz? Zrzuciła pantofle i zaczęła uciekać. Goń mnie, zawołała. Prawie traw nie dotykała. Hej! hej! Goń mnie, Boleś! Motyl, mówię wam. [...] Młoda była. Motyl, mówię. Nie słyszycie? Wy, jak z waszym się nie zgadza, to głuchniecie. [...] Goń mnie i goń, wołała. [...] Ale tchu mi brakło, nogi zaczęły mi sztywnieć, serce buch, buch. Stary jestem, gospodyni! Nie myślałem, że taki stary jestem! Czas mi widać umierać! Gospodyni wraca! Ale nie wróciła. Musiała tamtą stroną pójść [R, s. 11].

Dla Bolesia akt opowieści ma funkcjonować jako świadectwo, potwierdzenie prawdziwości historii. Powiedzieć, oznacza - w tym ujęciu - ustanowić stan rzeczy („mówię, była to była”), zwłaszcza że słowo w kulturze oralnej (w której osadzone są utwory Myśliwskiego) „konstytuuje świat, uobecnia go w słowach; stwarza" 20 .

Przywołany cytat jest rekonstrukcją dłuższej rozmowy, co może budzić wątpliwości interpretacyjne. Zaznaczę, że zatarcie granic pomiędzy konstrukcją pozornie zależną a niezależną - wpisane w strukturę dramatów Myśliwskiego ${ }^{21}$ - odgrywa istotną rolę i być może jednoznaczna odpowiedź na pytanie o sposób przytoczenia nie jest w ogóle możliwa ${ }^{22}$. Gdy uwzględni się kontekst oralności, charakterystyczny dla kultury chłopskiej, oraz potraktuje się dramat jako utwór przeznaczony na scenę (tekst mówiony), to słowa Gospodyni mogą nabrać charakteru konstrukcji niezależnej. Boleś - w typowy sposób dla narracji ustnej - przywołuje dialog, którego częścią są konkretne wypowiedzi Gospodyni. W prozie partie dialogowe zostałyby zaznaczone za pomocą myślnika lub słowa bohaterki przytoczono by bezpośrednio w cudzysłowie, co nadałoby im autonomii. Tutaj czytelnik ma do czynienia ze swobodną rekonstrukcją słów kobiety, co oddano jedynie czasownikami wołać, zawołać. Tego typu komentarze w narracji mówionej sygnalizują mowę niezależną. Można by je potraktować jako akompaniamenty narra-

20 B. Kaniewska, Opowiedziane. O prozie Wiestawa Myśliwskiego, Poznań 2013, s. 173. W tym kontekście warto dodać, że użycie mowy pozornie zależnej w utworach informacyjnych (naukowych i dziennikarskich) może wzbudzać etyczne wątpliwości i prowokować do pytań o nadinterpretację, a nawet prawdziwość wypowiedzi [D. Korwin-Piotrowska, Poetyka - przewodnik po świecie tekstów, Kraków 2011, s. 101]. Dla Bolesia z kolei opowieść w mowie pozornie zależnej staje się m.in. potwierdzeniem prawdziwości jego postrzegania rzeczywistości; dokładniej rzecz ujmując: gwarantem obecności Gospodyni.

21 Podobne przykłady znajdują się w Złodzieju i Drzewie.

${ }^{22}$ Ciekawe wydaje się to, $\mathrm{w}$ jaki sposób przykłady te zostałyby zinterpretowane w teatrze. Czy cały dialog odtwarzałby aktor grający Bolesia (wówczas interpretacja z mową pozornie zależną byłaby bardziej uprzywilejowana), czy również aktorka wcielająca się w Gospodynię brałaby udział w tej scenie (wtedy byłaby to mowa bezpośrednia)? 
cyjne dialogu ${ }^{23}$. Przywołane wypowiedzi zatem - przy takiej interpretacji - byłyby bezpośrednim przytoczeniem słów zjawy. Dwoista struktura dramatu nie pozwala jednak na tak jednoznaczną interpretację. Jeżeli skupi się na tekście (zapisie), to uprawnione wyda się potraktowanie przytoczeń wypowiedzi Gospodyni-zjawy jako (nietypowej) mowy pozornie zależnej lub przynajmniej konstrukcji granicznej24: zawieszonej pomiędzy mową bezpośrednią a pozornie zależną. Przeniesienie poetyki narracji mówionej na formę pisaną ma swoje konsekwencje. Słowa kobiety nie są bowiem w żaden sposób formalnie ani graficznie wyodrębnione: to Boleś „posługuje się” jej słowami. Porządek rozmowy (naprzemienność wypowiedzi jej uczestników) na pewno ułatwia wyodrębnienie głosu cudzego. Co więcej, Pastuch dwukrotnie używa czasowników charakterystycznych dla mowy pozornie zależnej wypowiedzianejej.

Wyznaczniki graficzne i interpunkcyjne, jak podkreśla Wojciech Górny, nie są podstawowym elementem strukturalnym przytoczenia ${ }^{26}$. Zdaje się, że badacz - za Lubomírem Doleželem - przytoczone słowa Gospodyni określiłby jako „niewłaściwą mowę wprost":

Termin nie jest najlepszy, ale rozróżnienie bardzo pożyteczne. Idzie o rzeczywistą wypowiedź przytoczoną ze wszystkimi jej wyróżnikami [...], lecz pozbawioną specyficznych dla przytoczeń cech interpunkcyjnych i graficznych ${ }^{27}$.

Niemniej, w epice sytuacja się inaczej kształtuje niż w dramacie. Kompetencje bezpośredniego przywoływania słów innych postaci i wplatania ich $\mathrm{w}$ narrację nie dziwią $\mathrm{w}$ przypadku wypowiedzi narratora, usytuowanego

${ }^{23}$ M. Głowiński, Dialog w powieści, w: tegoż, Gry powieściowe: szkice z teorii $i$ historii form narracyjnych, Warszawa 1973, s. 46.

24 Być może takie przykłady można by rozpatrywać jako mowę pozornie niezależną, odmianę pozornie zależnej, o której pisze m.in. Korwin-Piotrowska [Poetyka - przewodnik po świecie tekstów, s. 100, 103-106]. Budzi to jednak moje wątpliwości, ponieważ mowa pozornie niezależna $\mathrm{z}$ reguły ma charakter kryptocytatu, a w przypadku Requiem Boleś podkreśla fakt przywoływania słów Gospodyni. Piotrowska pisze, że forma pozornie niezależna występuje w sąsiedztwie mowy zależnej. Tutaj czytelnik ma do czynienia z mową bezpośrednią dramatis personae. Co więcej, u Myśliwskiego jest to nietypowa rekonstrukcja dialogu w dramacie, znamienna dla ludowej opowieści ustnej, która, jak sądzę, wymyka się klasyfikacjom.

25 Odnoszę się do podziału na mowę pozornie zależną wypowiedzianą i myślaną. Por. J. Jeziorska-Haładyj, Mowa i myśl (pozornie zależna), s. 170-175.

26 W. Górny, Składnia przytoczenia w języku polskim, w: A. Wierzbicka, System składniowo-stylistyczny prozy polskiego renesansu, Warszawa 1966, s. 306-310. Dla Górnego przytoczenie jest synonimem mowy niezależnej. Mowa pozornie zależna określona zostaje reprodukcją.

27 Tamże, s. 297. 
na wyższym poziomie nadawczym niż bohaterowie literaccy ${ }^{28}$. Inaczej jednak zdaje się to funkcjonować $\mathrm{w}$ dramacie, gdy jeden $\mathrm{z}$ bohaterów przytacza w ten sposób słowa innej postaci. Oba byty tekstowe są wobec siebie symetryczne. Zatarcie granic pomiędzy mową pozornie zależną a niezależną byłoby więc charakterystyczne właśnie dla dramatu. Ta niejednoznaczna, „podwójna" interpretacja zacytowanych fragmentów jest zatem uwarunkowana „dwoistą" strukturą utworu scenicznego ${ }^{29}$. Maria Olszewska zastanawia się, co autorom tworzącym uznane powieści ludowe przyniosło wykorzystanie formuły dramatycznej ${ }^{30}$. W przypadku Myśliwskiego (w kontekście zagadnienia mowy pozornie zależnej) odpowiedziałabym, że między innymi właśnie to: zatarcie granic pomiędzy różnymi typami wypowiedzi, które w prozie byłoby trudniejsze (lub niemożliwe?) do zrealizowania.

W przywołanej powyżej rozmowie Boleś sam akt opowieści traktuje jako świadectwo kontaktu z Gospodynią; w innych sytuacjach postać używa bardziej ekspresyjnego języka, by podkreślić swoje stanowisko:

Boleś: Gospodyni żyje! Nie umarła! Żyje! [...] O, dała mi ten różaniec. Weź im zanieś. Pokaż. Ale to ci ładnie $\mathrm{w}$ tym mundurze, powiedziała. Ale to ci ładnie, Boleś. Zawołaj tu mojego, niech pomoże mi wstać. Zawołaj Weronkę. Zawołaj tu wszystkich. Niech im Bóg wynagrodzi, że przyszli. Nie umarła! Żyje! [R, s. 108-109].

Słowa Gospodyni wprowadzone zostają nagle, dopiero w trzecim zdaniu pojawia się czasownik bezpośrednio sygnalizujący oddanie jej głosu. Ramą dla wypowiedzi kobiety jest dwukrotnie powtórzone wykrzyknienie Bolesia. Wypowiedź ta jest preludium do finałowego monologu postaci. Pastuch, jak romantyczni szaleńcy, ma dostęp do ukrytej wiedzy; do kontaktu z tamtym światem. Rozmawia z umarłą, a - jak wiadomo - to „najbardziej niemożliwa rozmowa ze wszystkich, jakie istnieją" ${ }^{31}$. U Bolesia ów kontakt przebiega w ciekawy sposób, ponieważ (w warstwie językowej) związany jest z mową pozornie zależną.

\footnotetext{
28 Taka sytuacja często ma miejsce w prozie Myśliwskiego.

${ }^{29}$ O dwoistej strukturze dramatu i lekturze dramatu zawieszonej w sferze "między” pisała m. in. Dobrochna Ratajczakowa. Zob. D. Ratajczakowa, Stuga dwóch panów: dwoisty żywot dramatu, „Teksty Drugie” 1990, nr 5-6, s. 91.

30 M.J. Olszewska, "Tragedia chłopska”, s. 13.

31 M. Janion, Niesamowita Słowiańszczyzna. Fantazmaty literatury, Kraków 2006, s. 70.
} 
Boleś odróżnia się od pozostałych bohaterów, co wiąże się z trzema faktami. Po pierwsze, mężczyzna widzi zjawę Gospodyni i rozmawia z martwą kobietą (co zostało już omówione). Pastuch wspomina również karczmarza Chaima, którego chciał sprowadzić na czuwanie. Czytelnik - na podstawie słów Gospodarza, który podkreśla, że Chaim nie żyje - może wywnioskować, że Żyd zginął przed wojną. Boleś zresztą kwestionuje pojęcie czasu linearnego ${ }^{32}$. Nadrealne kompetencje Bolesia (związane z kontaktem ze światem zmarłych) nie ograniczają się więc wyłącznie do rozmów z Gospodynią. Po drugie, Boleś jako jedyny potrafi „zapanować” nad technologią; przede wszystkim nad telewizorem, rekwizytem magicznym ${ }^{33}$. Pastuch wielokrotnie - za pomocą uderzenia w przedmiot - włącza i wyłącza ekran, gdy innym się to nie udaje. W swoim ostatnim monologu sprawia, że $\mathrm{w}$ telewizji pojawiają się konkretne obrazy: na przykład łąka, o której bohater opowiada. Wydaje się, że to między innymi ta kompetencja ujawnia metadramatyczny (niekoniecznie metateatralny ${ }^{34}$ ) charakter postaci Bolesia, którego wypowiedzi odsłaniają sposób funkcjonowania utworu, w scenie tej uwidacznia się diegetyczno-mimetyczny charakter dramatu.

Najbardziej nietypowa sytuacja to ta, gdy mężczyzna mówi, że widzi na ekranie siebie $\mathrm{w}$ kapeluszu kowbojskim, co wiąże się z zagadnieniem multimedialności w dramacie. Istotniejsze jednak, że to kolejny zabieg, który sprawia, że podaje się w wątpliwość status ontologiczny Bolesia. Obecni w pokoju negują jego słowa, jednak czytelnicy nie muszą podzielać ich opinii. Didaskalia informują: „na ekranie widzimy Bolesia na koniu z pistoletami przy bokach, pośród rozległej prerii, pędzącego stada krów" [R, s. 26]. Być może $\mathrm{w}$ ten sposób podmiot dramatyczny uprzywilejowuje perspektywę Bolesia; chce, by czytelnik bohaterowi wierzył, mimo że nie wierzą mu inni. W zacytowanym powyżej zdaniu kryje się informacja implikowana, dowartościowująca perspektywę wiejskiego szaleńca.

Warto również zauważyć, że w początkowych didaskaliach nie ma żadnego (choćby zaszyfrowanego) komunikatu o wątpliwym statusie ontologicznym Gospodyni; żadnej wskazówki, że postać występuje w dwóch odsło-

32 „Przed wojną, po wojnie. Latoś, onegdaj, przedwczoraj, wczoraj. U was zawsze musi jedno po drugim. Inaczej nie potraficie" [R, s. 84].

33 W. Baluch, Multimedialność jako nowa estetyka we wspótczesnej kulturze. Na przykładzie nowego polskiego dramatu, „Przegląd Kulturoznawczy” 2011, nr 1 (9), s. 122. O roli telewizji w chłopskim uniwersum zob. J. Betkowska, Telewizja a kres kultury chłopskiej - od "Awansu” Edwarda Redlinskiego do "Requiem dla gospodyni" Wiestawa Myśliwskiego, w: Myśl Myśliwskiego (studia i eseje), red. J. Olejniczak, Katowice 2018.

34 K. Ruta-Rutkowska, Metateatralność, metadramatyczność, metatekstowość w dramacie, „Pamiętnik Literacki" 2010, nr 2. 
nach: nieżyjącej kobiety oraz zjawy. "Gospodyni - w różnym wieku” - to jedyny komentarz na jej temat. Przy opisie wystroju izby czytelnik dowiaduje się jednak, gdzie złożono ciało zmarłej. Zacytowana informacja może dotyczyć scenicznych realizacji dramatu (np. w rolę Gospodyni wcielić się mają trzy aktorki). Warto jednak zauważyć, że z kobietą rozmawia wyłącznie Boleś. Swiat realny i nierealny nie funkcjonują na tych samych prawach. Do tego drugiego ma dostęp jedynie wiejski szaleniec (inaczej dzieje się w Drzewie ${ }^{35}$, w którym wszyscy bohaterowie widzą zjawy nieżyjących osób). Dlatego też tę - z pozoru błahą - charakterystykę postaci postrzegam jako dowartościowanie perspektywy Bolesia, który jako jedyny widzi Gospodynię „w różnym wieku".

Po trzecie, status ontologiczny Bolesia po raz kolejny zostaje zakwestionowany w scenie wypadku samochodowego. Zasugerowane jest, że to właśnie Boleś został przejechany przez Businessmana: „Turystka II: Czy ten ktoś był taki mały i w wiejskim kapeluszu? Smarkula (trzepoczac rękami): $\mathrm{O}$, tak machał rękami. Jak ptak" [R, s. 72]. Opis pasuje do Bolesia, zwłaszcza gdy uwzględni się powracający w utworze motyw ptaka. Co ważniejsze, po wypadku: „w ciemnościach rozlega się krzyk Gospodyni: „Zabili! Jezu Nazareński, zabili!". To jedyne miejsce ${ }^{36}$, w którym głos Gospodyni wyrażono w mowie niezależnej; uzyskuje on autonomię, której nie miał w przypadku pozornie zależnej. Jak rozumieć ów krzyk? Może być potwierdzeniem tezy, że to Boleś był uczestnikiem wypadku (zważywszy na bliską relację Pastucha i Gospodyni). Niepokojące jednak jest to, że żaden z bohaterów nic nie słyszy. Tak jak nie słyszeli wcześniejszych słów Gospodyni i nie wierzyli Bolesiowi, gdy je rekonstruował. Scena ta znów sugeruje, że tylko Boleś ma kontakt z nadrealnym światem. Czy w związku z tym didaskalia po raz kolejny nie uprzywilejowują punktu widzenia Pastucha? Czy odbiorca dramatu, skoro może przeczytać słowa Gospodyni, skoro ma do nich dostęp (inaczej niż postaci), nie przyjmuje perspektywy Bolesia? Znów okazuje się, że perspektywa podmiotu utworu, dysponenta reguł dramatycznego świata, pokrywa się z tą reprezentowaną przez Innego, który reprodukuje słowa zmarłej Gospodyni. Pozostali bohaterowie inaczej interpretują świat. Czytelnicy de facto wiedzą, że kobieta nie żyje, a pomimo to struktura tekstu sprawia, że dowartościowują oni perspektywę wiejskiego szaleńca; poznają prawdy, które bohater wyraża.

35 W. Myśliwski, Drzewo, Szczecin 1989.

36 Nie uwzględniam tutaj wypowiedzi Gospodyni-zjawy w różnych wcieleniach. 
Boleś w tajemniczy sposób wraca do izby i - po wizycie w pokoju Gospodyni - wygłasza słowa: „Gospodyni żyje!”. Czy w takim razie Businessman przejechał kogoś innego? Wtedy jednak krzyk Gospodyni nie miałby uzasadnienia. Czy Pastuch wrócił jako zjawa? Ta hipoteza wydaje się o tyle wątpliwa, że wszystkie postaci widzą mężczyznę, rozmawiają z nim, a - jak zostało wcześniej ustalone - jedynie Boleś ma kontakt ze światem nadrealnym. Być może zatem fakt, że bohater wraca do izby, wiąże się z jego „nadludzką siłą", o której mówił Gospodarz; czy ogólnie z jego niejednoznacznym statusem? Byłby to wówczas kolejny dowód na to, że Boleś funkcjonuje na pograniczu dwóch światów: realnego i fantazmatycznego. Dopiero w zakończeniu dramatu, podczas onirycznego monologu, bohater ostatecznie umiera, by w pełni połączyć się z Gospodynią. Co istotne, jest on świadom własnej śmierci. Uwage przykuwa czasownik w trybie dokonanym: „Hej, Gospodyni! [...] Umarłem. Boleś pada, śpiewanie przechodzi w forte" [R, s. 110].

Na zakończenie warto podkreślić, że w Requiem mową pozornie zależną posługuje się wiejski szaleniec. W przypadku niektórych wypowiedzi trudno ustalić granice pomiędzy głosem Bolesia a Gospodyni. Świadczą one o bliskiej relacji między dwojgiem bohaterów. Niekiedy nie da się jednoznacznie rozstrzygnąć, czy mamy do czynienia z mową pozornie zależną, czy bezpośrednim przytoczeniem (zwłaszcza $\mathrm{w}$ przypadku rekonstruowanych przez Bolesia całych partii dialogowych). Tę niejednoznaczność można wiązać z ludową narracją ustną, do której pisarz nawiązuje oraz samym gatunkiem dramatu, przeznaczonym do realizacji $\mathrm{w}$ formie ustnej. Trop ten wymagałby rozwinięcia (zwłaszcza w kontekście wszystkich dramatów Myśliwskiego), jednak warto zauważyć, że mowa pozornie zależna nie musi być - jak dotychczas $\mathrm{w}$ polskim literaturoznawstwie - kojarzona z psychologizacją postaci czy też prozatorską narracją personalną, lecz może wiązać się z ludowymi formami konstruowania ustnych opowieści.

Mowa pozornie zależna pozwala stać się Bolesiowi pośrednikiem pomiędzy dwoma światami: żywych i umarłych; służy Pastuchowi (między innymi) do tego, by przekazywać pozostałym bohaterom słowa Gospodyni. Wówczas rekonstruowane przez Bolesia sytuacje komunikacyjne odnoszą się do wizyjnego planu dramatu. Według ludowych wierzeń ciało, które nie zostało jeszcze złożone do grobu, znajduje się w fazie liminalnej, na pograniczu dwóch światów ${ }^{37}$. Być może dzięki temu Boleś, który również jest postacią

37 E. Wąchocka, Śmierć w ",nowych dekoracjach", s. 291. 
graniczną, ma zdolność komunikowania się z Gospodynią. Ewa Wąchocka zauważa, że:

Nie bez powodu rola medium powierzona została mającemu opinię wiejskiego "głupka" Bolesiowi. To paradoksalnie bodaj najrozsądniejszy zabieg, ażeby znaleźć dziś wyraz dla odwiecznej wiary człowieka, że jest on elementem szeroko pojętego porządku kosmologicznego, niekończącego się dla jednostki wraz ze śmiercią ciała ${ }^{38}$.

Jest to wiedza, którą czytelnik może zrekonstruować dzięki postaci Bolesia. Pastuch wyróżnia się spośród pozostałych bohaterów nie tylko w planie fabularnym, lecz także formalnym. Jego kompetencje kreacyjne (zdolność wywoływania obrazów) oraz językowe (tworzenie dwugłosowych opowieści w mowie pozornie zależnej) ujawniają metadramatyczny charakter postaci. Co więcej, jego punkt widzenia jest uprzywilejowany przez podmiot dramatyczny.

Boleś nie akceptuje śmierci Gospodyni; tak uważają pozostali bohaterowie, do tego wniosku prowadzą jego rozmowy z umarłą. Ale czy inni potrafią to zrobić? Mam tu na myśli przede wszystkim Gospodarza, który obok Pastucha - reprezentuje dawny chłopski porządek. Otóż sądzę, że nie. Gospodarz jest tak zaabsorbowany przywróceniem rytuału (którego we wsi czasu transformacji przywrócić się nie da), że tak naprawdę nie konfrontuje się z myślą o śmierci bliskiej osoby. Myśliwski więc za pomocą postaci Bolesia (mającego kontakt ze światem metafizycznym i przytaczającego za pomocą mowy pozornie zależnej słowa umarłej Gospodyni) pokazuje, że:

Śmierć nie jest kresem życia [...]. Przypomina [Myśliwski - dop. A.P.] o ich nieodróżnialności, a więc restytuuje taki sposób myślenia, który zakłada niemożność ich wyodrębnienia i odseparowania w porządku symbolicznym" ${ }^{39}$.

Tak samo nie da się odseparować głosów Bolesia i Gospodyni w mowie pozornie zależnej.

\footnotetext{
8 Tamże, s. 293.

39 E. Wąchocka, Kwartet dramatyczny Wiesława Myśliwskiego, s. 282. Wąchocka dochodzi do tej konstatacji dzięki analizie warstwy muzycznej dramatu. Zgadzam się z rozpoznaniami badaczki, chciałabym jednak pokazać, że analiza mowy pozornie zależnej i skupienie uwagi na postaci Bolesia mogą doprowadzić do tego samego wniosku. Boleś - jako epistemologicznie uprzywilejowany odmieniec - być może nie jest świadomy prawdy mówiącej, że śmierć jest częścią życia. Niemniej, to właśnie z tą refleksją - po analizie i interpretacji - zostaje czytelnik dramatu.
} 


\section{Bibliografia}

Bachtin Michaił (1970), Słowo w dziele Dostojewskiego, w: M. Bachtin, Problemy poetyki Dostojerwskiego, przeł. N. Modzelewska, Warszawa: Państwowy Instytut Wydawniczy, s. 275-403.

Baluch Wojciech (2011), Multimedialność jako nowa estetyka we współczesnej kulturze. Na przykładzie nowego polskiego dramatu, „Przegląd Kulturoznawczy”, nr 1, s. $120-126$.

Betkowska Jolanta (2018), Telewizja a kres kultury chłopskiej - od "Awansu” Edwarda Redlińskiego do "Requiem dla gospodyni" Wiesława Myśliwskiego, w: Myśl Myśliwskiego (studia i eseje), red. J. Olejniczak, Katowice: Wydawnictwo Uniwersytetu Śląskiego, s. 257-266.

Betkowska Jolanta (2019), Polski dramat ludowy (1945-1989), rozprawa doktorska obroniona na wydziale Filologiczno-Historycznym Akademii Pomorskiej w Słupsku.

Cerquiglini Bernard (1990), Mowa pozornie zależna i nowoczesność, przeł. M. Abramowicz, „Pamiętnik Literacki”, nr 4, s. 336-348.

Głowiński Michał (1973), Dialog w powieści, w: M. Głowiński, Gry powieściowe: szkice $z$ teorii $i$ historii form narracyjnych, Warszawa: Państwowe Wydawnictwo Naukowe, s. 37-58.

Głowiński Michał (1969), Powieść młodopolska. Studium z poetyki historycznej, Wrocław: Zakład Narodowy im. Ossolińskich.

Górny Wojciech (1966), Składnia przytoczenia w języku polskim, w: A. Wierzbicka, System składniowo-stylistyczny prozy polskiego Renesansu, Warszawa: Państwowy Instytut Wydawniczy, s. 279-405.

Hopensztand Dawid (1937), Mowa pozornie zależna w kontekście "Czarnych skrzydeł", w: Prace ofiarowane Kazimierzowi Wóycickiemu, Wilno, https://polona.pl/item/ mowa-pozornie-zalezna-w-kontekscie-czarnych-skrzydel,Njc4NjE3NzY/4/\#info: metadata [dostęp 09.06.2021].

Jakubowska-Cichoń Joanna (2010), Mowa przytaczana w narracjach Marguerite Duras, Kraków: Universitas.

Janion Maria (2006), Niesamowita Słowiańszczyzna. Fantazmaty literatury, Kraków: Wydawnictwo Literackie.

Jeziorska-Haładyj Joanna (2013), Tekstowe wykładniki fikcji. Na przykładzie reportażu i powieści autobiograficznej, Warszawa: Instytut Badań Literackich PAN Wydawnictwo.

Kaniewska Bogumiła (2013), Opowiedziane. O prozie Wiesława Myśliwskiego, Poznań: Wydawnictwo Naukowe UAM.

Kaniewska Bogumiła (1995), Wiesław Myśliwski, Poznań: Dom Wydawniczy Rebis.

Kopciński Jacek (2012), Wstęp, w: Trans/formacja. Dramat polski po 1989 roku. Antologia, t. 1, red. J. Kopciński, Warszawa: Instytut Badań Literackich PAN Wydawnictwo, s. 5-35.

Korwin-Piotrowska Dorota (2011), Poetyka - przewodnik po świecie tekstów, Kraków: Wydawnictwo Uniwersytetu Jagiellońskiego. 
Kulesza Dariusz (2012), Poza granicami literatury. Historia świata według Edwarda Redlińskiego, w: Spotkania w przestrzeni idei - słów - obrazów. Księga Pamiątkowa dedykowana prof. dr hab. Zofii Mocarskiej-Tycowej, red. J. Bielska-Krawczyk, K. Ćwikliński, S. Kołos, Torun: Wydawnictwo Naukowe Uniwersytetu Mikołaja Kopernika, s. $397-414$.

Kulesza Dariusz (2016), Epopeja. Myśliwski, Herbert, Mrożek, Białystok: Uniwersytet w Białymstoku.

Lewko Marian (2001), Świat wewnętrzny bohaterów chłopskich w dramaturgii Wiesława Myśliwskiego, w: O twórczości Wiesława Myśliwskiego (w siedemdziesiąta rocznice urodzin pisarza), red. J. Pacławski, Kielce: Kieleckie Towarzystwo Naukowe, s. 83-103 .

Myśliwski Wiesław (1973), Złodziej, „Dialog”, nr 7, s. 5-34.

Myśliwski Wiesław (1989), Drzewo, Szczecin: Glob.

Myśliwski Wiesław (2003), Kres kultury chłopskiej, Warszawa-Bochnia: Prowincjonalna Oficyna Wydawnicza, http://mbc.malopolska.pl/dlibra/docmetadata?id=3631 \&from=publication [dostęp 09.06.2021].

Myśliwski Wiesław (2012), Requiem dla gospodyni, w: Trans/formacja. Dramat polski po 1989 roku. Antologia, t. 1, red. J. Kopciński, Warszawa: Instytut Badań Literackich PAN Wydawnictwo, s. 627-632.

Olszewska Maria Jolanta (2001), "Tragedia chłopska”. Od W.L. Anczyca do K.H. Rostworowskiego. Tematyka - Kompozycja - Idee, Warszawa: Wydział Polonistyki Uniwersytetu Warszawskiego.

Ratajczakowa Dobrochna (1990), Sługa dwóch panów: dwoisty żywot dramatu, „Teksty Drugie", nr 5-6, s. 80-92.

Ruta-Rutkowska Krystyna (2010), Metateatralność, metadramatyczność, metatekstowość $w$ dramacie, „Pamiętnik Literacki”, nr 2, 113-138.

Tomasik Wojciech (1992), Kto mówi?: jeszcze o mowie pozornie zależnej, „Pamiętnik Literacki", nr 4, s. 112-128.

Tomasik Wojciech (1992), Od Bally'ego do Banfield [i dalej]. Sześć rozpraw o "mowie pozornie zależnej", Bydgoszcz: Wyższa Szkoła Pedagogiczna.

Wąchocka Ewa (2015), Śmierć w "nowych dekoracjach", w: Intymne - prywatne - publiczne, red. E. Wąchocka, Katowice: Wydawnictwo Uniwersytetu Śląskiego, s. 275-302.

Wąchocka Ewa (2018), Kwartet dramatyczny Wiesława Myśliwskiego, w: Myśl Myśliwskiego (studia i eseje), red. J. Olejniczak, Katowice: Wydawnictwo Uniwersytetu Śląskiego, s. 267-284.

Wołoszynow Walentin (1970), Z historii form wypowiedzi w konstrukcjach języka. (Próba zastosowania metody socjologicznej do zagadnień składni), tłum. Z. Saloni, w: Rosyjska szkoła stylistyki, oprac. M.R. Mayenowa, Z. Saloni, Warszawa: Państwowy Instytut Wydawniczy, s. 413-477.

Wóycicki Kazimierz (1922), Z pogranicza gramatyki i stylistyki. (Mowa zależna, niezależna i pozornie zależna), „Przegląd Humanistyczny”, t. 1, s. 75-100, https://polona.pl/ item/z-pogranicza-gramatyki-i-stylistyki-mowa-zalezna-niezalezna-i-pozorniezalezna,Njc4NzI4MDY/4/\#info:metadata [dostęp 09.06.2021]. 


\title{
Intertwined Voices: Free Indirect Discourse in Wiesław Myśliwski's Requiem dla gospodyni
}

\begin{abstract}
The article analyzes the drama Requiem dla gospodyni by Wiesław Myśliwski in the context of free indirect discourse as understood in literary criticism. The author of the article discusses the instances of this form of expression used in the utterances of Boleś, a shepherd and country madman of an unknown ontological status. She notices the problems with distinguishing between free indirect speech and the direct quoting of the late titular landlady [gospodyni] with whom Boleś established a strong bond. The author demonstrates that the shepherd plays a significant role both as a part of the storyline and a formal element because his creative capacity (building images) as well as linguistic (creating a binarrative in free direct speech) reveal his meta-dramatic character and privilege the dramatic subject.
\end{abstract}

Keywords: free indirect discourse, drama, character, point of view in drama 